\title{
Witch Hunting:A Form of Violence against Dalit Women in India
}

\author{
Tanvi Yadav'
}

\begin{abstract}
The Caste system is a social reality in India; despite constitutional rights of equality, protection from discrimination, and the ban on untouchability, discrimination against Dalit communities or Schedule Castes, still persists. Outside and within their caste, Dalit women face triple discrimination based on caste, class and-gender resulting in horrific acts of violence directed against them. Among the most common violent attacks on them across rural India, apart from sexual violence, are those related to declaring them witches, or accusing them of witchcraft, often leading to tragic outcomes such as death of victims.

Grabbing property, political jealousy, personal conflicts, getting sexual benefits, or settling old scores are found to be common reasons to declare a woman witch. However, deep down, it is a conspiracy of Brahmanical patriarchy to control resources and sustain caste hierarchy by hitting where it hurts the most - inflicting injuries on Dalit women. They face physical, economic, and cultural violence from social exclusion to being burnt alive. Most witchhunting victims have been noticed as either, old, widows, or single, women. This paper analyses violence against Dalit women with specific reference to witch- hunting. It explores the caste hierarchy, motives behind such crimes, also the failure of legal mechanisms and judicial institutions in eradicating the menace of witch-hunting.
\end{abstract}

\section{Keywords}

Witch-hunting, Caste hierarchy, Brahmanical patriarchy, Dalit women, superstitions.

\footnotetext{
'Research Scholar, Department of Public Policy, Law and Governance, Central University of Rajasthan, India

Email: tanvilI039I@gmail.com
}

(C) 2020 Tanvi Yadav. This is an open access article distributed under the terms of the Creative Commons Attribution License, which permits unrestricted use, distribution, and reproduction in any medium, provided the original author(s) and source are credited. 


\section{Introduction}

In concluding remarks during his presentation in Constituent Assembly, Dr. Bhim Rao Ambedkar had said, 'on January 26, 1950, (founding day of Indian Republic) we are going to enter into a life of contradictions. In politics, we will have equality, and in social and economic life, we will have inequality' (Rodrigues, 2002). The question of inequality in the form of the caste system still exists in India as a social reality even after seven decades of independence. Despite Constitutional provisions of the rights of equality, protection from discrimination, and the ban on untouchability, discrimination based on caste against a particular section officially known as scheduled castes, and socially known as Dalits is deeply rooted in Indian society.

The caste system is a 'legacy' to Indian society given by Brahmanism, whose brunt is borne mostly by women, more so the Dalit among them. It is a profoundly conservative socio-political ideology in which Brahmins occupy the highest place as exclusive guardians of the realm and as sole providers of wisdom on virtually every practical issue of this world; in which they can only take birth and cannot make (Bhargava, 2019). The Dalit ${ }^{1}$ woman is particularly the most vulnerable in the castegender hierarchy ladder. She has to face discrimination based on caste, class and gender, within her caste and outside. Dalit women face innumerable acts of violence; witch-hunting is one such form in which they suffer physically, psychologically, and economically.

Witch-hunting is a violent form of witchcraft belief. The belief in magic and witchcraft is common to all societies in the world. Witch-hunting had been prevalent even in early modern Europe and colonial America. During the fifteenth to eighteenth centuries, many women were put to death by the state in Salem witch trials (America) and Suffolk trials of Europe. In India, also the practice is ancient, and innumerable women have been killed. The patriarchal mindset of societies is considered to be the cause of the globally common phenomenon of witch-hunting. Caste or Brahmanical patriarchy in India is regarded as to be a main factor behind branding women as witches. Dalit activists claim that witch-hunting is part of caste-atrocities against Dalit women and a common way to kill them (Editorial, 2015).

Witch-hunting is a three-stage process viz. accusation, declaration, and persecution. Accusation means and includes 'accusing women of any harm occurred in the community or to the individual, such as the death of any person, child or animal, any disease in the village, natural disaster, or crop loss.' Declaration means to declare or brand the woman as a witch as she possesses some evil power, and exclude her socially. The so-called witches are identified through certain rituals by traditional witch-finders or witch doctors, who are variously known as the khonses, sokha, janguru,or ojha, and then perpetrators charge them for persecution (Mallick, 2008).

Persecution includes mental and physical torture, ranging from social exclusion, name-calling, psychological torture, lynching, or putting to death in any way. The concept of persecution refers to strategic attempts encouraged by dominant and influential groups in society, directed at groups that threaten them (Jensen, 2007). Accusing a Dalit woman of witchcraft and persecuting her is a standard weapon of the Brahmanical patriarchal set-up in rural India. It is an acknowledged fact that most of the witch-hunting victims are widows, single, older women, and social-economic marginalized women without any support (Barman, 2002; Kelkar \& Nathan, 1991; Mehra \& Agrawal, 2016). 
Witches are not identifying, at least in the Indian subcontinent. No one acknowledges or announces that they practise witchcraft or rituals that involve black magic and spells. In fact, they are named by powerful groups of society and their followers, who happen to belong to upper castes. In a majority of Indian states, any attempt to find out about a witch in a village invariably leads to Dalit women. The most common reasons to accuse and declare women witches are personal disputes or enmities, sexual desires towards women of the lower caste, coveting property of single women.

Due to existing beliefs on superstitions among people, such victims cannot protect themselves from mob crimes, including physical, emotional harm to ostracization. This paper highlights the nexus between Brahmanical patriarchy and superstitious beliefs, to perpetrate caste atrocities and maintain status quo vis-à-vis a social order based on graded inequality. It discusses the horrors and harassment faced by Dalit women on being branded as witches and points at the failure, and ignorance of laws dealing with the actual problem. The paper results from qualitative research with an exploratory approach, highlighting the Dalit women's issues and suggesting sociolegal solutions to prevent such social evils.

\section{History of Witch-Hunting}

In Early Modern Europe and Colonial America, witches were held responsible for disasters like famines, floods, drought, and epidemics resulting in massive deaths. Many of them were subjected to torture and trials by the state and executed. Sometimes to extort a confession, the state used torture on them (Purkiss, 1996). In the Western World, incidents of Witch-hunting disappeared as a consequence of socio-economic reforms after eighteenth century. However, in developing Nations like India, Witchhunting is still reported across state. In Europe and America, witchcraft was considered crimen exceptum, and the judiciary tried victims. Hence, judicial records became useful resources to extract information (Sinha, 2015). But in India, most witches' trials are public (cases of mob-incited violence and justice), and details are not easy to find. However, religious records and some colonial period information show that witch-hunting in the country is an old barbaric act of harassing women.

The term 'witch' or dayan is a prominent part of folk literature and culture since the dawn of civilization (Mohapatra, 2014). Saletore (1981) in Indian Witchcraft highlighted that the practice of witchcraft has been pervasively customary in India as well, especially among the rural and relatively isolated precincts.

During the colonial period, mass witch-hunting incidents occurred in 1857 in Chotanagpur region in eastern India (Sinha, 2007). The National Archive Records ${ }^{2}$ show that around a thousand women had been killed as witches in central India's plains alone in the early 19th century. During this period, the number of women killed as witches far exceeded those who died as sati (widow-immolation on husbands' funeral pyres), but the killings were neither reported nor given importance. Sati was apparent killing as a custom, but witch-hunting was a killing based on faith in evil powers with some hidden motives against women, particularly the unprotected and from lower castes. In the Brahmanical caste-based society, the death of Dalit women has no value. 
Estimate from the Rajputana community (Rajasthan), most commonly related to widow- immolation, indicate how common witch-killing was (Skaria, 1997).

Cases abound in British India, when authorities confiscated upper caste people's lands, they attributed the blame to witchcraft by Dalit women for their loss and started the $D e v i^{3}$ movement (witch-hunting exercise) against them. Women were singled out and asked to undergo a test conducted by a witch-doctor, especially of the so-called upper caste. In records, scholars found that victims' families often sought assistance from British authorities on the plea that their daughters, sisters, or wives had been identified as witches and needed help (Man, 2003). It was a general practice in rural areas, in the event of epidemics or famines, causing the widespread death of animals and humans, that a woman from the most vulnerable section of society was accused of witchcraft and hunted down as a witch.

\section{Dalit Women under Brahmanical Patriarchy}

The Varna system is the basis of the caste system in India. Brahmin writer Manu in Manusmriti described each caste's duties as a Varna system; he placed his caste on top and took the privilege of declaring other castes (Srinivas, 1995). Varna system includes the Brahmins; priests and scholars, Kshatriyas; rulers and warriors, Vaishyas; agriculturalists and merchants, and Shudras; labourers and service providers. Communities from these classes are called savarna or Caste Hindu. Apart from the savarnas, there exist a group of people who are avarna or antyaja i.e., outside the Varna system (Dube, 1990). They are considered the lowest and 'untouchable' in the orthodox Brahmanical beliefs and are expected to do unclean of 'impure and polluting' occupations such as sweeping, scavenging, tanning, and so on. However, Srinivas (1995) argued that if economic, social, and even ritual relations between a region's castes consider, these communities are an integral part of the system. They can be called the fifth Varna.

The caste system has resulted in alienating a group of people from the mainstream and causing their lower participation in societal argumentations, education, and employment, which lower their standard of life. Due to economic and social suppression, the group, officially known as Dalits or scheduled castes, stands excluded. Feminists also hold Manusmriti responsible for their secondary position in Hindu society. In Chapter nine, paragraph 290 of Manusmiriti, Manu wrote that for all types of black magic, a fine of two hundred (panas) should be imposed, as for witchcraft (Olivelle, 2004). Thus, the belief in witchcraft and practice of witch-hunting also prevailed in ancient times. The received texts of Manusmriti date circa $100 \mathrm{CE}$.

In general, women's subordination occurs across various social institutions and practices, and women's subjection is understood to be a structural condition. Feminists have described this structural subordination of women as patriarchy (Barker, 2010). In India, patriarchy is conjoined with the caste system and called 'Brahmanical patriarchy.' Historian Uma Chakravarti, who coined the term, argues that its crucial aspect was linkage to the caste order and the differential impacts it had on women at different levels in the caste hierarchy. Caste, class, and gender stratification are the three elements in establishing the social order in India, shaping the formation of Brahmanical patriarchy (Chakravarti, 1993).

Brahmanism supported a hierarchical structure with community limited to caste, and with differentiated patriarchal repression of women. Family patriarchy dominates 
the high-caste women, but state patriarchy dominates the Dalit women more, which was concerned with maintaining them as exploited labourers (Omvedt, 2000). Brahmanical patriarchy passes on thoughts that are profound and complex. It portrays how we live in social orders moulded by sexual orientation, station, and monetary connections, and shape them through our decisions and actions. Brahmanical patriarchy discusses the links between gender, caste, the economy, and the State. Chakravarti (1993) has inspected how, in ancient India, certain caste groups maintained land control (an economic asset) by regulations, which are endorsed by the state.

In his famous 1916 paper 'Castes in India,' Ambedkar offered the insight that the caste system thrives by its control on women; he deployed several arguments against Brahmanism and its twin, patriarchy (Rege, 2013). Brahmanism has gathered desperate myths like witchcraft and black magic together. Making unified cycles, developed a social fragment and used in holding back the Indian society and bagged down in a swamp of superstitions (Sau, 2003).

The caste system is estimated to affect around 260 million people. The most affected among them are women belonging to Dalit communities, who the so-called upper caste have excluded socially and exploited immensely. The vast majority of Dalit women are poor, landless wage labourers and lack access to basic amenities and entitlements. They are subjugated by patriarchal structures, both in the general community and within their own families (Centre for Alternative Dalit Media, 2001). According to National Campaign for Dalit Human Rights (NCDHR), 'every hour two Dalits face assaults, every day three women of Dalit community are raped, two Dalits are murdered, and homes of two Dalits are torched' (Ambedkar, 2017).

Caste-affected women face multiple challenges, including lack of access to resources, lack of education opportunities, land, essential services, and justice. Witchcraft accusation and Witch-hunting is yet another tool to suppress and subordinate women by asserting their so-called inferior status. In rural areas, a Dalit woman lives in terror and fear because she knows that dominated people can target her anytime to seek revenge, or assert authority, or simply suppress.

\section{Motives for Promoting Witch-Hunting}

\section{Sustaining Caste and Patriarchy}

Brahmanism uses various tactics to keep its control over society; hence even after having equality as the soul of India's constitution, it is full of inequalities. One of the many tactics deployed to sustain the hegemony of caste includes witch-hunting. It helps to terrorize women and reinforce the patriarchal mindset. It has been noticed that most witch-hunting victims hail from schedule castes, blamed for all calamities and misfortune befalling society (Mathur, 2004). Dalit activist P. G. Ambedkar (2017) claims not a single case of witch-hunting against upper Caste or Brahmin women has been identified until now. The victims of witch-hunting suffer physical and mental brutality in shocking forms such as lynching, naked parade, ostracization, and even being burnt alive by mobs (Partners for Law in Development (PLD), 2015).

Such acts of physical violence are so brutal that they are committed with the purpose to terrorize such that the community does not dare to raise their voices for justice. For instance, in a witch- hunting incident in a village in Jharkhand state (East India), four Dalit women were brutally lynched after public shaming in a gory manner. 
Before death, they faced public humiliation; their faces were painted black, heads were shaved, stripped and paraded round the village with a mob chasing and beating them brutally with iron rods. The rods were pierced through their body; as a result they bled to death (Sinha, 1984).

Initially, one lower caste woman was branded as a witch by the village authority and blamed for a child's death in a landlord family. When other Dalit women stood in her support, the village authority was offended and planned to set an example so that no other woman in the village dared to have a stand-up with them. In the course of this, all the four women were branded as witches by the village witch doctor, who got 600 rupees from the perpetrators, to identify these four women as witches. During the ritual of witch-identification, the witch-doctor forced the women to drink a solution, after which the women started behaving differently, and were thus branded witches (Sinha 1984).

Ramachandran (2012) cites another incident in which a Dalit woman was branded a witch as upper caste people did not approve of her mother-in-law as the sarpanch (elected head of village committee) and the development work that she wanted to do. The victim told press reporters that they had victimized her because she belonged to the Dalit community. The upper caste men of the village had made some unreasonable demands of her mother-in-law; when she refused to fulfill their desires, they started torturing her daughter in law after branding her a witch. The upper caste community decided to socially boycott of the victimized family. Police also took time to file their complaint, the victim alleged.

Only through constitutional provisions and reservation, the Dalit community has found entry in specific spheres such as legislative institutions, government jobs and state-run educational institutions of higher education. However, Brahmanism finds a mode to keep them suppressed and humiliated, and takes control from them in one way or another. One of the most common explanations forwarded by feminists is that witch-hunting is gender violence wherein vulnerable women are targeted by men in power. Power could be manifested in economic wealth, spiritually, or in social positions. The witch hunters, on their part, seemed to be motivated by communitarian religious concerns; personal enmity, or material gain was often the motive behind the murder of witches (Mallick, 2008). Brahmanical patriarchy placed Dalit women at the bottom of the social hierarchy and considered them an object of sexual gratification. Witch-hunting resulted in the successful enforcement of a patriarchal order, forcing women into a position subordinate to men.

\section{Extending Superstitions}

The crime of witch-hunting involves masses, where a village is often involved, including the victim's community and sometimes family. It is still debatable how the Dalit men are caught in caste trap and stand against their own community women. In this case, superstitions play an essential role wherein men are blinded by illogical reasoning leading them to believe that women are the reason for their destruction. Witch doctors have a significant role in spreading these propositions and winning the trust of Dalit men. However, it is unfortunate that many people readily accept unscientific views due to lack of quality education and scientific temper.

People have blind faith in religion, culture, and traditions and the associated beliefs and superstitions become a matter of faith rather than logic. In India, the number of religious places is more than educational institutions and hospitals, reflecting people's 
inclination towards supernatural powers and fantasies. Sau (2003) quotes historian Damodar Dharmanand Kosambi: 'Ideas (including superstition) become a force once they have gripped the masses. There is less scope for scientific experimentation or proof by other means in the context of spirituality and society.'

In a village in Jharkhand state one day at dusk, nine villagers stormed into the house of a woman, shouting, 'she is a witch' and dragged her out by her hair as her six children watched helplessly. They accused her of casting some evil spell to destroy their crops by fire. They beat her with rods, and tortured her in many ways and locked her in a room for four days. Police investigation established that the attack was spurred by a powerful landowner in the village who used local superstition to maintain his authority over the village (Lakshmi, 2005).

Witch-hunting and superstitions go hand in hand in perpetuating Brahmanical patriarchy. Perpetrators spread superstitions to perform witch-hunting in bid to control Dalit women and manage Dalit men.

\section{Witch-hunting and Hidden Agenda of Brahmanism}

The caste system, superstitions, patriarchy, illiteracy, and poverty are the leading causes that have sustained the barbaric practice of witch-hunting. Apart from establishing power over fellow humans, control over use of resources is gained by targeting Dalit women be it with sexual assault or witch hunting. There are some personal gains for the upper caste people that help sustain caste hierarchy.

\section{Grabbing Property and Sexual Advances}

After women, the second important thing for caste to capture for its existence is resources. Assets in the form of field, home, land, or livestock are the resources that can easily be grabbed in witch-hunting cases. Barman (2002) argues that witch-hunt in India is the outcome of property disputes. He further stated that victims of witch-hunts are mostly childless widows who have property rights, which will pass on their nearest male relative after their death. By accusing them of witchcraft, these men inherit land immediately.

In specific land related violence in rural areas, women are targeted and victimized in witch-hunting by land mafias together with the dominated caste to grab land and settle their interest behind the veil of superstition. By declaring them 'witches, and forcing them out of the house, or getting them banished from the village, it becomes easy to acquire the victim's relinquished property. Targeting single women with an aim of usurping property is the primary motive of witch-hunting violence (Mehra \& Agrawal, 2016). In some rural tribal areas a widow's right to property is denied if other family members can prove that she is a witch. (Kelkar \& Nathan, 1991).

In August 2017, 'a 40-year-old Dalit woman was allegedly branded a witch, stripped, beaten up mercilessly and made to eat human excreta in Rajasthan's Ajmer district. The victim was sleeping in her house when people attacked her and dragged her out of her home; the attackers forced her to drink sewer water, eat faeces, and beat her with iron rods. She succumbed to the injuries inflicted on her. The village panchayat (local governing body) asked the attackers to take a bath in Pushkar pond to 'wash their sins'; the panchayat wanted to hush up the matter. However, Tara Ahluwalia, a social activist tracking the case, told reporters, that the victim had been branded as a witch to usurp her property. Her husband had died a month ago and 
she had a minor son. The main accused in the case (attackers) had masterminded the conspiracy against her (Wadhawan, 2017).

In the Chandmoni Tea Estate Case of 2002, a man died in the village due to lack of proper medication. The relatives and other villagers took advantage of his death to declare five women witches and killing them because they had some land disputes and personal rivalry (Chaudhuri, 2013). Soma Chaudhuri (2013) found that there are usually some prior conflicts, such as a property dispute between the accuser and the accused. The local beliefs in the 'casting evil eyes superstition' and power were manipulated to launch a witch-hunt against the accused woman.

In some incidents, rejection of sexual advances has been reason for branding a woman witch. In most such cases, the targeted women are helpless and deprived, and fall easy prey to power when they hit back and rejects such advances (Partners for Law in Development, 2014). Witch-hunting violence is mostly associated with caste atrocities perpetrated against Dalits; there is ample evidence that shows that victimization is used to punish social and sexual transgressions (Mehra \& Agrawal, 2016). In most cases, after declaring women a witch, the perpetrators keep her outside of the village and take sexual advantage of her. Rape is also common as a witchhunting punishment, mostly done by the dominant caste in a gang.

\section{Socio-economic and Political Dominance}

The witch becomes the symbol of all oppression and misery and thus, witchcraft is no longer a personal matter. It is now a concern of the community, a label that the 'moral' entrepreneurs have successfully exploited to their advantage (Chaudhuri, 2013). Witch-hunting motives are not static or limited to superstitions, or occult beliefs. The violence associated with caste atrocities is often similar to the cruelty perpetrated in witch-hunting (Mehra \& Agrawal, 2016). Often, witch-hunting has been used to punish women who question social norms (Lakshmi, 2005).

Politics has also played a part in spreading superstitions and promoting witch hunts in the country. In 2003, at a function in Patna, the Union (federal) Minister from Bihar state felicitated fifty one witch doctors and said: 'I strongly believe that whatever they (witch doctors are) doing is pure science, and they protect villages from evil spirits' (Sau, 2003). Politicians (mostly dominant caste) have used superstitions, black magic, or illogical belief to gain political power. Ranjit Sau (2003) said that we have two kinds of evil spirits, one in a village in the form of witch doctors and others are in cities in the shape of politicians, which arises a dual system of superstition in India.

Politics of superstitions offers an escape for politicians as it helps divert public attention from the need/demand for a better life and inability to provide basic facilities such as education, health services, and transport services in their constituencies. Sometimes class politics within caste politics also has been used to suppress Dalit women in the name of witch-hunting. The improved economic status of scheduled caste men are no different from that of upper caste landlords; their better position has brought no respite to women of their caste from oppression unleashed by the upper caste landlords. The ugly Jharkhand incident (Sinha, 1984) is a tragic example of this.

Sundar (2001) and Federici (2010) have highlighted the need to understand that indepth causes of Indian witch hunts are related to recent changes that rural people face, such as the social crisis caused by economic liberalism, forcing people to compete for limited resources. Dungdung (2009) in her article Hunting witch or hunting women, 
says 'the greed for property and depriving women of traditional property rights is a sidelined fact. Illiteracy, low educational levels, and superstitious beliefs are reasons fit enough to be the icing on the cake.' Thus the misogyny and casteist nature of the State is equally responsible for witch hunts.

\section{The Legal Position in India}

Every year, hundreds of unreported incidents of witch-hunting occur in every state. After being declared a witch, women are tonsured, harassed, ostracized, physically tortured, banished from their village, and even forced to consume human excreta (at times) (Das, 2005). A UN report stated that researchers recorded 25000 witchhunting cases in India between 1987 and 2003 (Federici, 2008)the global expansion of capitalism ensured that this persecution would be planted in the body of colonized societies, and, in time, would be carried out by the subjugated communities in their own name and against their own members. (Federici, 2010) The National Crime Records Bureau (NCRB) indicates that approximately 2937 women were killed in India from 2001 to 2019 on alleged charges practicing witchcraft. Only in the year 2019, 102 killings took place (NCRB, 2019). Witch-hunting is prevalent in most Indian states; majority cases were reported from Bihar, Jharkhand, Chhattisgarh, Odisha, Uttar Pradesh, Rajasthan, Assam and Madhya Pradesh.

Despite such disturbing figures on the incidence of witch hunting, there is no national law in the country against this gruesome practice although states like Assam, Bihar, Jharkhand, Chattisgarh, Rajasthan and Odisha have already criminalized the practice. However, at the international level, the Universal Declaration of Human Rights (UDHR), 1948, International Covenant on Civil and Political Rights (ICCPR), 1966, and International Covenant on Economic, Social and Cultural Rights (ICESCR), 1966 stand violated by witch-hunting violence. The UDHR protects against any discrimination and promotes equality before the law. It also confirms the right to life and liberty to every human being. India is associated with ICCPR; it supports equality between women, men, and transgender and ensures equal rights to all humans in civil and the political sphere and prohibits others from subsuming anyone's fundamental rights. India also acceded to ICESCR, six articles of this may be linked with witchhunting, particularly to the instances of social boycott and property deprivation.

In 1993, India signed the Convention on the Elimination of All Forms of Discrimination against Women (CEDAW). It agreed to eliminate discrimination and social cruelty against women. CEDAW Committee ${ }^{4}$ categorizes witch-hunts as a form of violence against women and has urged many countries, including India, to take action on witchcraft accusations. In 2009, the CEDAW Special Rapporteur report called upon national governments and the United Nations to 'ensure that all killings of alleged witches are treated as murder and investigated, prosecuted, and punished accordingly. ${ }^{5}$ CEDAW asked governments 'to take all appropriate measures such as modifying or abolishing existing laws, regulations and customs and practices, which constitute discrimination against women. ${ }^{6}$

Coming back to India, at the national level, the Constitution of India, Indian Penal Code, The Drugs and Magic Remedies (Objectionable Advertisement) Act 1954, Schedule Castes and Schedule Tribes (Prevention of Atrocities) Act, 1989, and The Protection of Human Rights Act, 1993 can be associated with witch-hunting atrocities. 
While some states such have specific local Acts on prevention of witch-hunting, others are in the process of criminalizing the offence. Maharashtra state passed India's first anti-superstition law called the Prevention and Eradication of Human sacrifice and other inhuman, evil, and Aghori practices and the Black magic Act 2013. Dr. Narandra Dabholkar, the founding member of the Maharashtra Andhashraddha Nirmoolan Samiti, an organization dedicated to eradicating superstitions, demanded the first time anti-superstition law. The Act in its schedule mentioned twelve practices as harmful superstitions, including belief in evil power and black magic, which can be related to witch-hunting. However, this anti-superstition law was dubbed anti-Hindu or antiBrahmininsm law by fundamentalists, and unfortunately, Dr. Dabholkar was shot dead by two men in August 2013. It suspected that fundamentalist right-wing Hindu forces were behind his murder. Central Bureau of Investigation (CBI) as arrested right-wing Hindutva activists but still, justice has not been delivered so far (Banerjee, 2020).

Based on Maharastra's anti-superstition act, in Karnataka state passed the Karnataka Prevention and Eradication of Inhuman Evil Practices and Black Magic Bill, 2017 while in Kerala, Kerala Prevention and Eradication of Inhuman Evil Practices, Sorcery and Black Magic Bill, 2019, is still pending in legislation opposed by rightwing politics. The objective of these anti-superstition laws is to promote scientific temper (Mehra \& Agrawal, 2016). The Federation of Indian Rationalist Associations, a body of 65 rationalist organizations from different parts of the country, has also demanded a law to ensure the separation of religion from politics, administration, and education. The law should ban state-sponsored religious activities. The state will never progress unless superstitions are removed; affording the quacks to fool everyone is dangerous for the country (Das, 2005).

The Supreme Court of India laid down that religion is a matter of personal faith. Still, if there is little knowledge or false knowledge of religion or understood in a narrow sense, it breeds superstition, fanaticism, and fundamentalism, which becomes an enemy of humanity. Superstitions that have crept in the name of religion become harmful to society. The court held that superstition could not justify any killing, much less a planned and deliberate one. ${ }^{7}$ In Hulikal Nataraju v. the State of Karnataka ${ }^{8}$, the court discusses the evils of superstition: Citing examples of human sacrifice and witch-hunting, it held that

The enormous damage done by these harmful superstitions is that they redirect attention from the primary cause and lead to a defeatist attitude of helpless acceptance. These superstitions promote exploitation, untouchability, complexity, caste, creed, gender, and varna based inequalities. They became instruments in the hands of some to exploit, cheat, and deceive the ignorant people.

Rajasthan high court ${ }^{9}$ also laid down that:

The evil practice of declaring the woman a witch and killing her is an offense which should not be tolerated suppose efficient improvement in these matters is not reported. In that case, the state of Rajasthan will be considered as slow in taking measures and backward and ineffective in bringing out appropriate legislation and taking steps on atrocities committed on women.

In Bhim Turi v. the State of Assam, ${ }^{10}$ Gauhati High Court termed witch-hunting as a social menace and observed that 'as a phenomenon (it) is rooted in flawed quasireligious beliefs, old socio-cultural traditions blended with extreme superstitious 
practices.' The Court also held that 'witch hunting is the worst form of human rights violation.'

In the 1991 case, Gaurav Jain v. the State of Bihar, ${ }^{11}$ the Supreme Court Bench comprising Justice Joymalya Bagchi J., termed witch-hunting as gross violence of human rights. It laid down specific guidelines directing the state governments to eradicate the social evil of witch-hunting. Based on those guidelines, after more than 20 years, the Prevention of Witch-Hunting Bill, 2016, was framed, but the law still has not been considered a need of the country by the legislative.

The role of police administration is very pathetic in witch-hunting cases; in a study done by Partners of Law Development, out of forty-eight cases, one third never reach the police (PLD, 2013). As per police and judiciary records, witch-hunting incidents in which brutal physical violence occurs and is publicly orchestrated by a group of accused, criminal justice comes into play (Mehra \& Agrawal, 2016). The verbal abuses, public humiliation, and social exclusion never count on that account in any law available at the national or local level.

Gender violence is rooted in deep cultural and religious beliefs propounded by Brahmanical patriarchy. 'Change is often intensely resisted by the communities perpetrating the act of hostility. Thus there is a vast gap between human rights and the violence that women face at the local level as gender violence is an ambitious study that creates tensions between global law and local justice' (Merry, 2009). Dalit women are the victims at a large scale of all the physical, sexual, or psychological acts of violence against women mentioned as a crime in both national and international Laws. Witch-hunting is one of the most heinous forms of violence that Dalit women are subjected to in India.

\section{Conclusion}

Witchcraft accusations and witch-hunting violate human rights and fundamental freedoms of the right to life, liberty, including social and economic equality. Incidents of witch-hunting shame India's claim of a democracy that provides equality in gender, caste, race, and claims achievements in literacy, humanity, and gender sensitivity. It reflects on the state's failure to spread education and health facilities, inculcate respect for women, promote scientific temperament, and make equality a social reality.

Law and criminal justice system have failed to understand the motives behind witch-hunting and the core reasons for such menace, therefore could not respond effectively. The reality of this problem is deeply ingrained in a society that cannot be highlighted only by data. Only some of the most horrific cases get reported, while most witch-hunting incidents go unreported and unrecorded. Since most atrocities revolve around the fundamental issues of land, wages, and entitlements; poverty and powerlessness, are viewed as the breeding grounds of such violence. However, such reasoning does not go deep enough because it leaves out the primary motive behind such atrocities- Brahmanism.

Faith in witchcraft and witch-hunting in society results from a combination of superstitious belief, socio-economic and political conspiracy by Brahmanical patriarchy. The caste system encourages such evil practices since these are used as a tool to suppress lower caste communities, especially women, and impose control over them. In this set-up, Dalit women bear the triple burden of caste, class, and gender. 
Dr. Ambedkar (1979) said caste is nothing but Brahmanism incarnate. Without a robust movement against Brahmanism, Dalit emancipation is impossible. Brahmanism is the poison that has spoiled Hinduism. Non-acceptance is the primary cause of persisting social inequality based on gender and caste in India. The shamefulness is so blatant that people or the state do not even recognize the crimes of witch-hunting. There is a need to understand that witch-hunting is very real in many parts of India and targeted at the women from Dalit communities. Silence is a potent enemy of social justice (Sen, 2005), especially in the form of law and order.

There is an urgent need to fill-up the legal gaps and overcome the loss of livelihoods and property, dislocation, and of human dignity of the victims as witches is a proven tool to conduct atrocities against the marginalized Dalit women. Sensitizing the police and welfare departments and establishment of NGOs for this purpose could prove beneficial. There is a vital need to make a stringent law or add the Indian Penal Code with a rigorous punishment as criminalization is the only an aspect of justice. The law is considered an instrument of change; however, witch-hunting requires more than a social change, such as abolishing the caste system, gender hierarchy, and economic inequality.

\section{References}

Ambedkar, B. R. (1979). Babasaheb Ambedkar's writings and speeches, Vol 1 (1st ed.; G. of M. Education Department, Ed.). Dr. Ambedkar Foundation, Ministry of Social Justice \& Empowerment, Govt. of Maharashtra.

Ambedkar, P. G. (2017). Dalit Women and the witches. Retrieved from Newsclick website: https://www.newsclick.in/dalit-women-and-witches

Banerjee, S. (2020, August 21). CBI probe: Seven years on, no justice for Dr. Dabholkar. The Hindu. Retrieved from https://www.thehindu.com/news/cities/mumbai/cbi-probe-sevenyears-on-no-justice-for-dr-dabholkar/article32407976.ece

Barker, C. (2010). Cultural Studies: Theory and Practice (3rd ed.). Sage Publication, London.

Barman, M. (2002). Persecution of Women: Widows and Witches. Kolkata: Indian Anthropological Society.

Bhargava, R. (2019, July 23). What does it mean to oppose Brahmanism? The Hindu.

Centre for Alternative Dalit Media. (2001). Research Study on Violence against Dalit Women in Different States of India by studying the Sources of Materials that are Available and Conducting Interview of the Perpetrators, Victims and Witnesses. Retrieved from http:// ncwapps.nic.in/pdfReports/ViolenceagainstDalitWomen.pdf

Chakravarti, U. (1993). Conceptualising Brahmanical Patriarchy in Early India. Economic and Political Weekly, 28(14), 579-585. Retrieved from https://www.epw.in/journal/1993/14/ special-articles/conceptualising-brahmanical-patriarchy-early-india-gender-caste

Chaudhuri, S. (2013). Extending the logic of Funtional Explanations- A Theoretical Model to Explain the Victimization Process during an Indian Witch Hunt. In N. Jaishankar, K and Ronel (Ed.), Global Criminology: Crime and Victimization in a Globalized Era (pp. 315333). New York: CRC Press.

Das, P. (2005). Witch-hunts in Orissa. 22(11).

Dube, S. C. (1990). Indian Society. National Book Trust, India.

Dungdung, G. (2009). Hunting Witches or Hunting Women? Retrieved September 9, 2019, from Adivasi Hunkar website: https://adivasihunkar.com/2009/07/25/hunting-witches-orhunting-women/ 
EPW Editorial. (2015). Witch-hunts and victimisation. Economic and Political Weekly, 50(29).

Federici, S. (2008). Witch-hunting, globalization, and feminist solidarity in Africa today. Journal of International Women's Studies, 10(1), 21-35.

Federici, S. (2010). Women, Witch-Hunting and Enclosures in Africa Today. Sozial. Geschichte Online, 3, 10-27.

Jensen, G. F. (2007). The Path of the Devil: Early Modern Witch Hunts. New York: Rowman and Littlefield.

Kelkar, G., \& Nathan, D. (1991). Women, Witches and Land rights. In G. Kelkar \& D.Nathan (Eds.), Gender and Tribe: Women, Land and Forest (pp. 88-109). London: Zed books Ltd.

Lakshmi, R. (2005, August 8). From Superstition to Savagery. The Washington Post. Retrieved from https://www.washingtonpost.com/wp-dyn/content/article/2005/08/07/ AR2005080700947.html?itid=lk_inline_manual_13

Mallick, A. (2008). Witch-hunting in 1857. Economic and Political Weekly, 43(39), 118-119.

Man, E. G. (2003). Santhals and Santhals. Mittal Publications, New Delhi.

Mathur, K. (2004). Countering Gender Violence: Initiatives Towards Collective Action in Rajasthan. Sage Publication.

Mehra, M., \& Agrawal, A. (2016). Witch-hunting in India? Do We Need Special Law? Economic and Political Weekly, 51(13), 51-57.

Merry, S. E. (2009). Human Rights and Gender Violence: Translating International Law into Local Justice. Oxford University Press, London.

Mohapatra, D. S. (2014). Witch Hunting : A tool of terrorization across the World and its Legal Ramifications. International Journal of Academic Research, 1(4), 81-90.

NCRB. (2019). National Crime Records Bureau. Retrieved from https://www.google.com/ search?q=ncrb\&rlz=1C1RLNS_enIN811IN811\&oq=ncrb\&aqs=chrome..69i59j69i57j014j 69i6012.4084j0j7\&sourceid $=$ chrome\&ie $=$ UTF-8

Olivelle, P. (2004). The Law Code of Manu. London: Oxford University Press.

Omvedt, G. (2000). Review: Towards a Theory of Brahmanic Patriarchy. Economic and Political Weekly, 35(4), 187-190. Retrieved from https://www.epw.in/journal/2000/04/ book-reviews/towards-theory-brahmanic-patriarchy.html

Partners for Law in Development. (2013). Piecing together Perspectives on Witch Hunting: A Review of Literature. New Delhi.

Partners for Law in Development. (2014). Contemporary Practices of Witch Hunting: A Report on Social Trends and the Interface with Law.

Partners for Law in Development. (2015). Witch hunting in Assam: Individual, Structual and Legal Dimentions. New Delhi.

Purkiss, D. (1996). The Witch in History. Routledge, London.

Ramachandran, S. K. (2012, February 8). Upper caste men brand Dalit sarpanch's daughter-inlaw "witch." The Hindu. Retrieved from https://www.thehindu.com/news/national/otherstates/upper-caste-men-brand-dalit-sarpanchs-daughterinlaw-witch/article2869614.ece

Rege, S. (2013). Against the Madness of Manu: B.R Ambedkar's Writings on Brahmanical Patriarchy. New Delhi: Navayana.

Rodrigues, V. (2002). The Essential Writings of B.R. Ambedkar. Oxford University Press.

Saletore, R. N. (1981). Indian witchcraft. New Delhi: Abhinav Publications.

Sau, R. (2003). Recognition to Witchcraft. EPW, 38(51-52), 5325-5326. Retrieved from https:// www.epw.in/journal/2003/51-52/commentary/recognition-witchcraft.html

Sen, A. (2005). The Argumentative Indian. Allen Lane.

Sinha, S. (2007). 1857: Witch-hunts, Adivasis, and the Uprising in Chhotanagpur. Economic and Political Weekly, 42(19), 1672-1676. 
Sinha, S. S. (2015). Culture of Violence or Violence of Cultures?Adivasis and Witch-hunting in Chotanagpur. Anglistica, 19(1), 105-120.

Sinha, U. (1984). Bihar- Landlord 's Witch-Hunt. EPW, 19(19), 790-791.

Skaria, A. (1997). Women, Witchcraft and Gratuitous Violence In Colonial Western India. Past \& Present, 155(1), 109-141.

Srinivas, M. N. (1995). Social Change in Modern India. Orient Blackswan.

Sundar, N. (2001). Divining Evil: The State and Witchcraft in Bastar. Gender, Technology and Development, 5(3), 425-428.

Wadhawan, D. A. (2017, August 14). Rajasthan: Dalit woman branded witch, beaten up, stripped, made to eat faeces in Ajmer. INDIA TODAY. Retrieved from https://www.indiatoday.in/india/ story/rajasthan-ajmer-dalit-woman-tortured-beaten-to-death-faeces-1029585-2017-08-14

\section{Endnotes}

1 The word Dalit means split, broken and scattered in Sanskrit. It also means a person not belonging to one of the four Brahminic castes. The word was popularized by B. R. Ambedkar (1891-1956), who included all depressed people irrespective of their caste into the definition of Dalits.

2 National Archives of India, New Delhi (hereafter NAI), Foreign Department (hereafter FD), Political, 16 Feb. 1853, nos. 121-3.

3 A witch finding test.

4 The United Nations Committee on the Elimination of Discrimination against Womenhttps://www.ohchr.org/en/hrbodies/cedaw/pages/cedawindex.aspx\#: :text=The $\% 20$ Committee $\% 20$ on $\% 20$ the $\% 20$ Elimination $\% 20$ of $\% 20$ Discrimination $\% 20$ against $\% 20$ Women\%20(CEDAW,rights\%20from\%20around\%20the\%20world.

5 U.N. Human Rights Council, Rep. of the Special Rapporteur on Extrajudicial, Summary or Arbitrary Executions, 57, 68, U.N. Doc. A/HRC/11/2 (May 27, 2009).

6 Convention on the Elimination of All Forms of Discrimination, http://www.ohchr.org/ Documents/ProfessionalInterest/cedaw.pdf

7 Sushil Murmu v. State of Jharkhand 20042 SCC 338

8 W.P. no.1750/2008, H.C.(Kant.). 1 September,2010

9 State of Rajasthan v Shankar 2010

10 Criminal Appeal No. 79 OF 2013, The Gauhati High Court

111991 Supp (2) SCC 133 